\title{
The Effect of Work Discipline and Work Motivation on Employee Performance at Jamu Jago Joyokusumo Herbal Medicine Factory
}

\author{
Leni Kris Tanti \\ Faculty of Economics and Business , Narotama University Surabaya, Indonesia \\ Lenikris97@gmail.com
}

\begin{abstract}
This research is a survey research with a quantitative approach. The sample of this research is all employees of Jamu Jago Joyokusumo Factory Banyuwangi, amounting to 40 employees with the sampling technique using the census method. Data collection using a questionnaire while data analysis using multiple linear regression test. The results of this study indicate that: (1) Work Discipline has no partially significant effect on the Employee Performance of Jago Jago Joyokusumo Jamu Factory. This can be proven by the T test of 0.576 which is greater than 0.05. (2) Work motivation has a partially significant effect on the Employee Performance of Jago Jago Joyokusumo Jamu Factory. This can be proven by the T test of 0.000 which is less than 0.05 . (3) Work Discipline and Work Motivation simultaneously have a significant effect on the Employee Performance of Jamu Jago Joyokusumo Factory Employees. This can be proven by the F test of F count 8.174 with a significant level of 0.001 , so the significant value is much smaller than 0.05
\end{abstract}

Keywords :

Employee Performance, Work Discipline, Work Motivation.

\section{Preliminary}

\subsection{Background}

Human resource management (HR) has an obligation to build employee behavior and HR management also has a duty to create the best performance for the company and employees. The role of human resources (HR) is very important in an organization / company and basically organizations not only expect capable, skilled human resources, but most importantly they must be willing to work actively and have the desire to achieve optimal work results. Good performance is performance that is in accordance with organizational standards and supports the achievement of organizational goals and seeks to improve the ability of human resources, because this is the key to improving employee performance. The maximum performance of Jamu Jago Joyokusumo Jamu Factory employees is expected by the factory. According to Lisman et al. (2019) performance is the behavior displayed by each worker as a work performance produced by employees in accordance with their role in the company.

Work discipline is an attitude of respecting, appreciating, obeying and obeying the rules that apply both written and unwritten and being able to carry out and not avoid receiving sanctions if he violates the rules, duties, authority given to him (M, 2019). Work discipline is very important for the factory because it is where the awareness and willingness of a person to obey all the rules set by the factory. Darmawan et al.(2019) say that motivation is a process that explains the intensity, direction and conditions of effort to achieve a goal.

Jamu Jago Joyokusumo in Banyuwangi is a leading herbal medicine factory in the Banyuwangi Regency. Many herbs contain health benefits and increase immunity. The owner of this herbal medicine used to sell home herbal medicine and over time the home herbal medicine turned into a factory called Jamu Jago Joyokusumo. Joyokusumo jago jamu factory has experienced a fairly rapid development and provides benefits to the community, and is ready to face the challenges in the future. Each individual has a variety of different characters, this results in less cohesiveness in work, sub-optimal performance, resulting in low morale and reduced employee motivation which greatly affects employee performance.

The aim of this research is :

1. Analyze the effect of work discipline partially on the employee performance of Jamu Jago Joyokusumo Jamu Factory.

2. Analyze the effect of work motivation partially on the employee performance of Jamu Jago Joyokusumo Jamu Factory. 
3. Analyze the effect of work discipline and work motivation simultaneously on the performance of the employees at Jamu Jago Joyokusumo Factory.

\section{Literature Review}

\subsection{Human Resources}

Basically, the most important thing to achieve a maximum goal is to start with the thing that most respects the achievement of that goal, namely human resources (HR). Human resources (SDM) is a planning, organizing, implementing and supervising the procurement, development, remuneration, integration, maintenance and separation of labor in order to achieve organizational goals according to (Darmawan et al. 2019).

\subsection{Work Discipline}

Work discipline is a tool used by managers to communicate with employees so that they are willing to change behavior and as an effort to increase one's awareness and willingness to comply with all company regulations (Iskamto et al. 2020).

\subsection{Work motivation}

Work motivation according to Herdian et al. (2020) is motivation formed from the attitude of employees in dealing with work situations in the company. motivation is a condition or energy that moves employees who are directed or aimed at achieving company organizational goals.

\subsection{Employee performance}

Employee performance is the level of achievement of results for the implementation of certain tasks. Company performance is the level of achievement of results in order to realize company goals. Management is all activities carried out to improve the performance of a company or organization, including the performance of each individual and work group in the company (Maiti \& Bidinger, 1981).

\subsection{Framework of Mind}

Based on the description above, a frame of mind is made regarding the effect of work discipline and work motivation on employee performance at Jago Jago Joyokusumo Herbal Medicine Factory. As illustrated as follows:

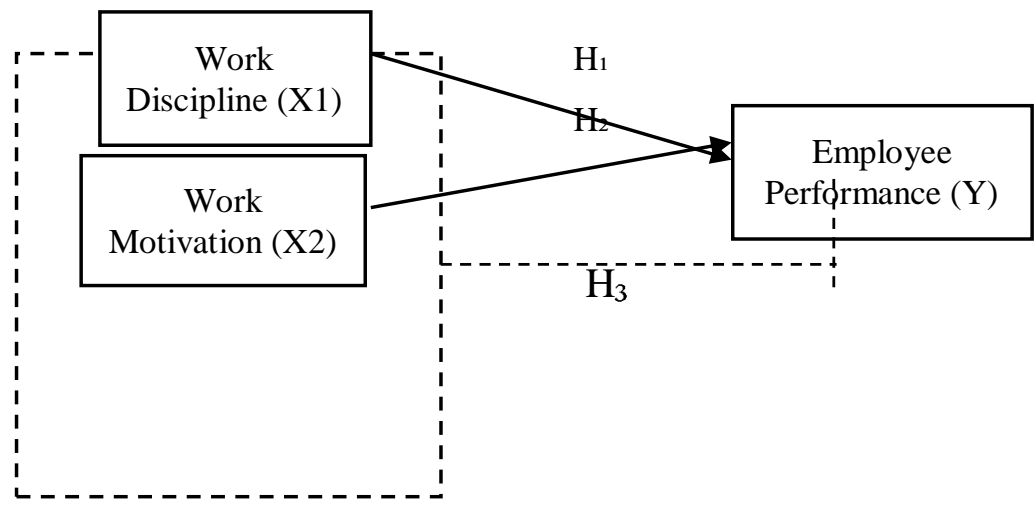

Flochart

\subsection{Research Hypothesis} follows:

Based on the description of the framework and theoretical basis above, the hypothesis of this study is as

H1: Work discipline has a partially significant effect on employee performance.

H2: Work motivation has a partially significant effect on employee performance.

H3: Work discipline and work motivation simultaneously have a significant effect on employee performance.

\section{Research Methods}

\subsection{Population}

Population is a generalization area consisting of objects / subjects that have certain quantities and characteristics that are determined by the researcher to study and then draw conclusions (Susilana, 2015). The population in this study were 40 employees of Jamu Jago Joyokusumo Factory in Banyuwangi. 


\subsection{Sample}

The sample is a part of the whole as well as the characteristics of a population (Hutabarat et al., 2017) In this study, no sampling was carried out, because all members of the population as many as 40 employees of the Jago Joyokusumo Jamu Factory would be used as respondents.

\subsection{Data collection technique}

The data collection technique in this study was to use an agket / questionnaire. The questionnaire is a list of written questions that have been formulated, and with this questionnaire the respondents will answer. The questionnaire was chosen because it is an efficient data collection. While the weakness of the respondents themselves is that the questions have been determined and the respondent does not provide answers that are appropriate to the circumstances.

\subsection{Research Variables and Operational Definitions}

1. Independent variables (Independent), the independent variables to be used in this study are Work Discipline $\left(\mathrm{X}_{1}\right)$ and Work Motivation $\left(\mathrm{X}_{2}\right)$.

a. Work Discipline (X1) The indicators are time discipline, responsibility discipline, regulatory discipline.

b. Work motivation (X2) indicators, physiological needs, security needs, social needs, self-esteem needs, actualization needs.

2. Bound variables (dependent), the dependent variable that will be used in this study is Employee Performance (Y).

a. Employee Performance (Y) Indicators, Quality, Quantity, Timeliness, Effectiveness, Independence, Work Commitment.

\section{Technical Analysis}

\subsection{Validity test}

The validity test in this study uses item analysis, which is to correlate the score of each item with the total score which is the sum of each item score, and if there is an item that does not meet the requirements, the item will not be studied further (Kusnadi \& Mutoharoh, 2016) .

\subsection{Reliability Test}

He use of reliability testing by researchers is to assess the consistency of objects, data and whether the instruments that have been used several times to measure the same object will roduce the same data (Lrviana, 2019)

\subsection{Classic assumption test 4.3.1 Normality test}

The normality test is whether the residual value is normally distributed or not and a good regression modal is that it has a normally distributed residue, so it is often an error that the normality test is performed for each variable.

\subsubsection{Multicollinearity Test}

The multicollinearity test is to determine whether there is a high correlation between the independent variables in a multiple linear regression model.

\subsubsection{Heteroskedastizitas Test}

The heteroscedastity test was examined for unequal differences between one residue and other observations. One of the regression models that qualify is that there is a similarity in the variance between the residues of one observation and another called homoscedasticity.

\subsubsection{Multiple Linear Regression Analysis}

Multiple linear regression is a statistical method in which the independent variable and independent variable are more than one. The form of the multiple regression equation is as follows.

$\mathrm{Y}=\mathrm{a}+\mathrm{b}_{1} \mathrm{X}_{1}+\mathrm{b}_{2} \mathrm{X}_{2} \ldots+\mathrm{bnXn}+\mathrm{e}$

Information :

$\mathrm{Y}=$ dependent variable

$\mathrm{a}=$ constant 
$\mathrm{b}=$ regression coefficient

$\mathrm{X}_{1}=$ The first independent variable

$\mathrm{X}_{2}=$ second independent variable

$\mathrm{E}=$ error

\subsection{T Test (Partial)}

The $\mathrm{T}$ test basically shows how far the influence of one independent variable individually explains the variation of the dependent variable (Durkheim, 1999).

\subsection{F Test (Simultaneous)}

The F test basically shows whether the same independent variables or independent variables included in the model have a joint influence on the dependent variable or the dependent variable. Used for F statistics (Soeprajitno et al., 2018).

\subsection{Coefficient of Determination}

The coefficient of determination is a tool to measure the ability of the model to explain the variation in the dependent variable. The coefficient of determination is either zero or one. And a small $\mathrm{R}$ value means that the ability of the independent variables to explain the variation in the dependent variable is very, very limited. And conversely, if the value is close to 1 , it means that the independent variables provide almost all the information needed to predict the dependent variables (Rahman et al., 2020) .

\section{Research Results and Discussion}

\begin{tabular}{cc}
\multicolumn{2}{c}{ Table 1 . Reliability Results } \\
\hline \multicolumn{2}{c}{ Reliability Statistics } \\
\hline Cronbach's & N of \\
alpha & Items \\
, 887 & 27 \\
\hline \multicolumn{2}{l}{ Source: SPSS Output Data }
\end{tabular}

Based on table above, the reliability test results show that the research data has a Cronbach's alpha value of 887 , more than 0.6 , so it can be said that each questionnaire variable is reliable.

Based on the table2., all variables of Work Discipline (X1), Work Motivation (X2) and Employee Performance (Y) show significant results $t$ count is greater than $r$ table. So it can be concluded that all statement items are declared valid. 
Table 2. Validity Results

\begin{tabular}{ccccc}
\hline \multicolumn{5}{c}{ Table 2. Validity Results } \\
Variabel & Indikator & $\begin{array}{c}\text { Corrected } \\
\text { Item-Total } \\
\text { Correlation }\end{array}$ & R-Table & Remarks \\
& X1.1 & 0,821 & 0,312 & Valid \\
& X1.2 & 0,851 & 0,312 & Valid \\
& X1.3 & 0,748 & 0,312 & Valid \\
Work & X1.4 & 0,668 & 0,312 & Valid \\
Discipline & X1.6 & 0,699 & 0,312 & Valid \\
(X1) & X1.7 & 0,477 & 0,375 & Valid \\
& X2.1 & 0,702 & 0,312 & Valid \\
& X2.2 & 0,748 & 0,312 & Valid \\
& X2.3 & 0,640 & 0,312 & Valid \\
& X2.4 & 0,413 & 0,312 & Valid \\
Work & X2.5 & 0,682 & 0,312 & Valid \\
motivation & X2.6 & 0,604 & 0,312 & Valid \\
(X2) & X2.7 & 0,575 & 0,312 & Valid \\
& X2.8 & 0,834 & 0,312 & Valid \\
& X2.9 & 0,782 & 0,312 & Valid \\
& X2.10 & 0,736 & 0,312 & Valid \\
& X2.11 & 0,531 & 0,312 & Valid \\
& Y.1 & 0,636 & 0,312 & Valid \\
& Y.2 & 0,891 & 0,312 & Valid \\
Employee & Y.3 & 0,787 & 0,312 & Valid \\
performance & Y.4 & 0,888 & 0,312 & Valid \\
(Y) & Y.5 & 0,588 & 0,312 & Valid \\
& Y.6 & 0,686 & 0,312 & Valid \\
\hline & Source: SPSS Output Data &
\end{tabular}

Table 3. Multiple Linear Regression Test Coefficients $^{\mathrm{a}}$

\begin{tabular}{ccccc}
\hline Model & $\begin{array}{c}\text { Unstandardized } \\
\text { Coefficients }\end{array}$ & $\begin{array}{l}\text { Standardized } \\
\text { Coefficients }\end{array}$ & T & Sig. \\
\hline
\end{tabular}

\begin{tabular}{ccccccc}
\multicolumn{1}{c}{ B } & & Std. Error & Beta & & \\
\hline 1 & (Constant) & 6.886 & 5.731 & & 1.201 & .237 \\
& Disiplin Kerja & .074 & .131 & .078 & .565 & .576 \\
& Motivasi Kerja & .352 & .087 & .554 & 4.035 & .000 \\
\hline
\end{tabular}

a. Dependent Variable: Kinerja Karyawan

$\mathrm{Y}=6.886+0.074(\mathrm{X} 1)+0.352(\mathrm{X} 2)$

Information :

$\mathrm{Y}=$ Employee Performance

$\mathrm{A}=$ Constant value

$\mathrm{B} 1, \mathrm{~B} 2$ = Variable Coefficient

$\mathrm{X} 1=$ Work Discipline

$\mathrm{X} 2=$ Work Motivation

$\mathrm{E}=$ error

1. The constant value is 6,886, this indicates that if Work Discipline (X1) and Work Motivation (X2) are 0, then the Employee Performance is 6,886

2. The coefficient value of Work Discipline (X1) is 0.074 , this indicates that if Work Discipline (X1) increases by one unit, then Employee Performance $(\mathrm{Y})$ will increase by 0.074 units.

3. The coefficient of Work Motivation (X2) is 0.352. This indicates that if Work Motivation (X2) increases by one unit, then Employee Performance (Y) will increase by 0.352 units. 
Table 4. R Square Test and Adjusted R Square Model Summary ${ }^{\mathrm{b}}$

\begin{tabular}{cccccc}
\hline Model & $\mathrm{R}$ & $\mathrm{R}$ Square & $\begin{array}{c}\text { Adjusted R } \\
\text { Square }\end{array}$ & $\begin{array}{c}\text { Std. Error of } \\
\text { the Estimate }\end{array}$ & $\begin{array}{c}\text { Durbin- } \\
\text { Watson }\end{array}$ \\
\hline 1 & $.554 \mathrm{a}$ & .306 & .269 & 3.00823 & 1.782 \\
\hline
\end{tabular}

a. Predictors: (Constant), Motivasi Kerja, Disiplin Kerja

b. Dependent Variable: Kinerja Karyawan

Source: SPSS Output Data

Based on the table above, in the $\mathrm{R}$ square test of determination, the $\mathrm{R}$ coefficient value of 0.554 can be obtained, which means that the variables of Work Discipline (X1), Work Motivation (X2), and Employee Performance (Y). The coefficient of determination or R square is 0.306 , which means that the Work Discipline variable (X1) and the Work Motivation variable (X2) can explain the variation in employee performance by $30.6 \%$ while the rest $(100 \%-30.6 \%=69.4 \%)$ are explained by other variables not examined in this study.

\begin{tabular}{|c|c|c|c|c|c|c|c|c|}
\hline & \multicolumn{8}{|c|}{$\begin{array}{l}\text { Table } 5 . T \text { test } \\
\text { Coefficients }^{\mathrm{a}}\end{array}$} \\
\hline & \multirow[t]{2}{*}{ Model } & \multicolumn{2}{|c|}{$\begin{array}{l}\text { Unstandardized } \\
\text { Coefficients }\end{array}$} & \multirow{2}{*}{$\begin{array}{c}\text { Standardi } \\
\text { zed } \\
\text { Coefficie } \\
\text { nts } \\
\text { Beta }\end{array}$} & \multirow[t]{2}{*}{$\mathrm{t}$} & \multirow[t]{2}{*}{ Sig. } & \multicolumn{2}{|c|}{$\begin{array}{l}\text { Collinearity } \\
\text { Statistics }\end{array}$} \\
\hline & & B & $\begin{array}{l}\text { Std. } \\
\text { Error }\end{array}$ & & & & $\begin{array}{c}\text { Tolera } \\
\text { nce }\end{array}$ & VIF \\
\hline \multirow[t]{3}{*}{1} & (Constant) & 6.886 & 5.731 & & 1.201 & .237 & & \\
\hline & $\begin{array}{l}\text { Disiplin } \\
\text { Kerja }\end{array}$ & .074 & .131 & .078 & .565 & .576 & .994 & 1.006 \\
\hline & $\begin{array}{l}\text { Motivasi } \\
\text { Kerja }\end{array}$ & .352 & .087 & .554 & 4.035 & .000 & .994 & 1.006 \\
\hline
\end{tabular}

a. Dependent Variable: Kinerja Karyawan

Source: SPSS Output Data

Based on the table above, the T test (partial) shows that the Work Discipline variable (X1) has a significant value of $0.576>0.05$. This shows that the Work Discipline variable (X1) does not have a partially significant effect on the Employee Performance variable (Y). Work Motivation Variable (X2) obtained a significant value of $0.000<0.05$. This shows that the Work Motivation variable $(\mathrm{X} 2)$ has a partially significant effect on the Employee Performance variable (Y).

\begin{tabular}{ccccccc}
\multicolumn{8}{c}{ Table 6. F test } \\
ANOVA $^{\mathrm{a}}$ \\
\hline \multirow{2}{*}{ Model } & $\begin{array}{c}\text { Sum of } \\
\text { Squares }\end{array}$ & Df & Mean Square & F & Sig. \\
& Regression & 147.945 & 2 & 73.972 & 8.174 & $.001^{\text {b }}$ \\
& Residual & 334.830 & 37 & 9.049 & & \\
& Total & 482.775 & 39 & & & \\
\hline
\end{tabular}

a. Dependent Variable: Kinerja Karyawan

b. Predictors: (Constant), Motivasi Kerja, Disiplin Kerja

Source: SPSS Output Data

Based on the table above, the F test (simultaneous) is the result of the F test simultaneously with F counting to 8.174 with a significance level of $0.001^{\mathrm{b}}$. Then the significant value is much smaller than 0.05 , meaning that the variables of Work Discipline (X1) and Work Motivation (X2) simultaneously have a significant effect on Employee Performance (Y). 
Table 7. Multicollinearity Test

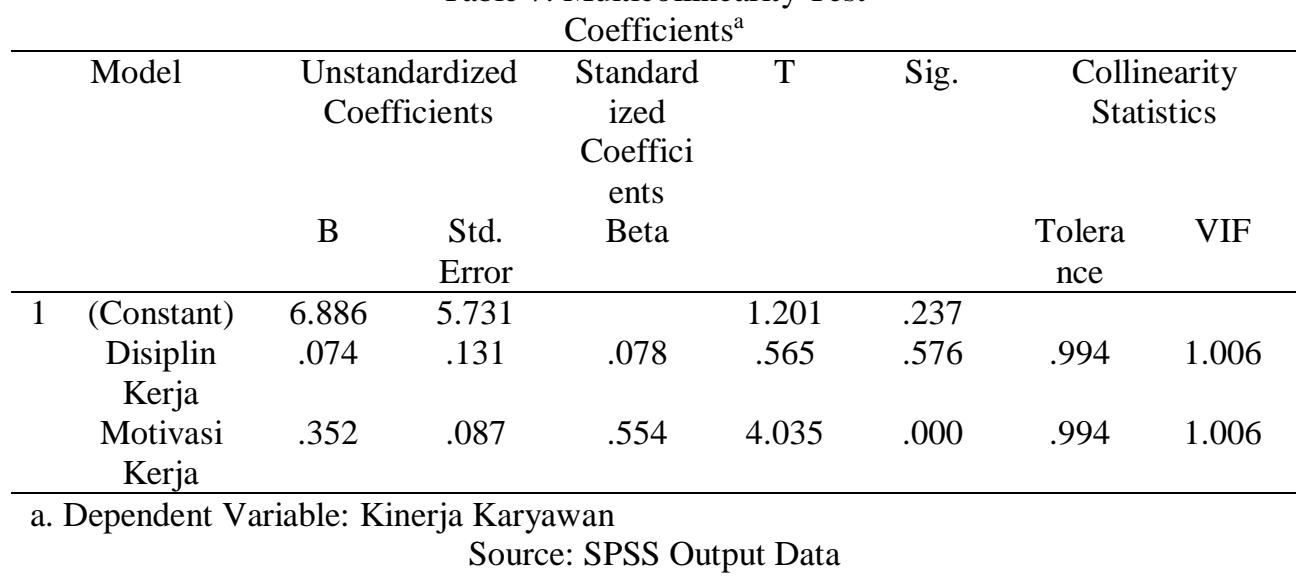

Based on the table above, the tolerance value for each independent variable is greater than 0.1 and the VIF value for each independent variable is less than 10. It means that it can be concluded that there are no symptoms of multicollinearity.

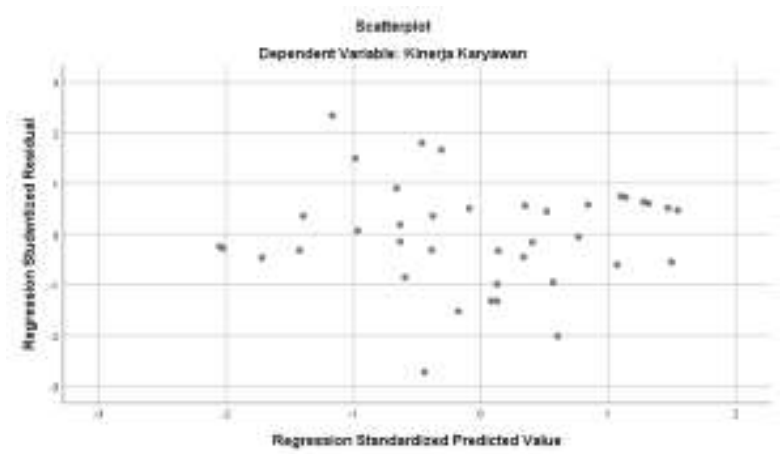

Figure 8. Heteroscedasticity Test

Source: SPSS Output Data

Based on the image above, it can be seen that the data distribution is irregular and does not form a certain pattern, and is spread above and below the number 0 on the $\mathrm{Y}$ axis. And it can be concluded that in this regression model there is no heteroscedasticity problem.

\begin{tabular}{|c|c|c|c|c|c|c|}
\hline \multicolumn{7}{|c|}{$\begin{array}{c}\text { Table 9. Glejser Test } \\
\text { Coefficients }^{\mathrm{a}}\end{array}$} \\
\hline \multirow{2}{*}{\multicolumn{2}{|c|}{ Model }} & \multicolumn{2}{|c|}{$\begin{array}{l}\text { Unstandardized } \\
\text { Coefficients }\end{array}$} & \multirow{2}{*}{$\begin{array}{c}\text { Standardized } \\
\text { Coefficients } \\
\text { Beta }\end{array}$} & \multirow[t]{2}{*}{$\mathrm{T}$} & \multirow[t]{2}{*}{ Sig. } \\
\hline & & B & Std. Error & & & \\
\hline \multirow[t]{3}{*}{1} & (Constant) & -1.002 & 3.395 & & -.295 & .770 \\
\hline & Disiplin Kerja & .153 & .078 & .307 & 1.966 & .057 \\
\hline & $\begin{array}{l}\text { Motivasi } \\
\text { Kerja }\end{array}$ & -.020 & .052 & -.060 & -.385 & .702 \\
\hline
\end{tabular}

Source: SPSS Output Data

Based on the table above in the Glejser test it is said that to strengthen the heteroscedasticity test which is the result of the Work Discipline variable (X1) with a significant 0.057, Work Motivation (X2) with a significant 0.702 which is greater than 0.05 , it can be concluded that the Work Discipline variable ( X1), Work Motivation (X2) and Employee Performance (Y) Free from heteroscedasticity symptoms. 


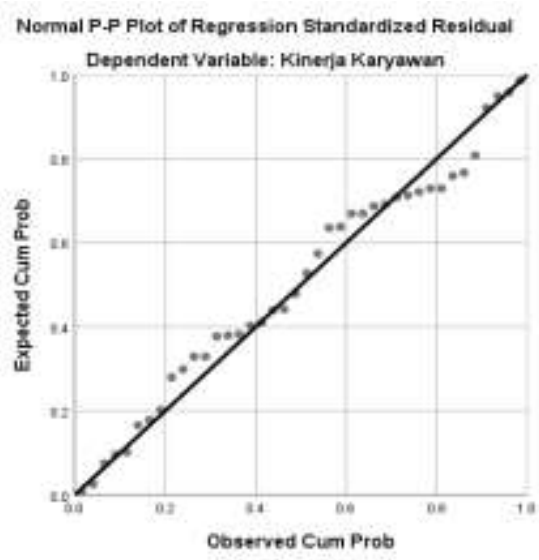

Figure 8. Heteroscedasticity Test Source: SPSS Output Data

Based on the picture above, it shows that all existing data is normally distributed, because all the data spreads to form a straight diagonal line, then the data meets normal assumptions or follows the line of normality.

Table 11. Kolmogrov Smirnov test

One-Sample Kolmogorov-Smirnov Test

\begin{tabular}{ccc}
\hline & & Unstandardized Residual \\
Normal Parametersa,b & Mean & 40 \\
& & .0000000 \\
Most Extreme Differences & Std. Deviation & Absolute \\
& Positive & 2.93008452 \\
& Negative & .102 \\
Test Statistic & & .102 \\
& & .089 \\
Asymp. Sig. (2-tailed) & .102 \\
\hline
\end{tabular}
a. Test distribution is Normal.
b. Calculated from data.
c. Lilliefors Significance Correction.

Data Source: SPSS Output

Based on the table above, the Kolmogrov Smirnov test is used to strengthen the normality test, where the significant results are $0.200>0.05$, it can be concluded that the residual value is normally distributed.

\section{Clonclusion and Suggestion \\ 6.1 Conclusion}

Based on the results of the research analysis that has been carried out, it can be concluded as follows:

1. Work Discipline has no partially significant effect on the Employee Performance of Jamu Jago Joyokusumo Herbal Medicine Factory. This can be proven by the T test results of 0.576 which is greater than 0.05 .

2. Work motivation has a partially significant effect on the Employee Performance of Jamu Jago Joyokusumo Herbal Factory. This can be proven by the T test of 0.000 which is smaller than 0.05 .

3. Work Discipline and Work Motivation have a significant effect simultaneously on the Employee Performance of Jamu Jago Joyokusumo Factory Employees. This can be proven by the F test of F count 8.174 with a significance level of 0.001 , so the significant value is much smaller than 0.05 .

\subsection{Suggestion}

Based on the above conclusions obtained, the following suggestions can be given:

1. For the Jago Joyokusumo Jamu Factory 
a. For Jamu Jago Joyokusumo Jamu Factory to further improve employee performance by paying attention to work discipline and work motivation so that future performance will be better.

b. In the aspect of Work Discipline, the company should make a firm rule, this can be done by providing guidance / direction for employees who behave / behave not in accordance with the rules set by the company.

c. In the aspect of Work Motivation, it is advisable for the leader of Jamu Jago Joyokusumo Herbal Medicine Factory to increase Work Motivation from the leadership to employees by giving gifts or appreciation for outstanding employees.

d. In the aspect of employee performance, the company should pay more attention to employee performance to complete work in excess of a predetermined volume. This also greatly supports the achievement of company goals.

2. For further research and it is hoped that the results of this study will be used as a reference for further researchers. In addition, it can add other variables that can affect employee performance at the Joyokusumo Jamu Factory in Banyuwangi. Associated with other variables that can affect performance, from the results of the research conducted by the author, there are other variables that will be examined by further research, namely the variable job satisfaction, compensation, work environment, leadership.

\section{References}

Darmawan, A. S., Hamid, D., \& Mukzam, M. D. (2019). PENGARUH MOTIVASI KERJA DAN KEMAMPUAN KERJA TERHADAP KINERJA KARYAWAN (Studi Pada Karyawan PT PLN (Persero) Distribusi Jawa Timur Area Pelayanan dan Jaringan Malang). Jurnal Lentera Bisnis, 8(1), 1-9.

Durkheim, E. (1999). Chapter - iii research methodology 3.1. 1985, 122-141.

Herdian, P. D., Nugroho, R., \& Sumiati, S. (2020). the Effect of Work Motivation and Spiritual Intelligence on Employee Performance With Organizational Citizenship Behaviour (Ocb) As Intervening Variables. JMM17: Jurnal Ilmu Ekonomi Dan Manajemen, 7(01), 1-12. https://doi.org/10.30996/jmm.v7i01.3541

Hutabarat, B. A., Pohan, A. E., \& Adam, A. (2017). The Effectiveness of Shared Reading Strategy toward Students' Reading Achievements. ANGLO-SAXON: Jurnal Ilmiah Program Studi Pendidikan Bahasa Inggris, 8(1), 75. https://doi.org/10.33373/anglo.v8i1.986

Iskamto, D., Yapentra, A., Budi Ansori, P., \& Jupri, M. (2020). Effect of Working Discipline Toward Performance: An Empirical Investigation. KnE Social Sciences, 2020, 492-501. https://doi.org/10.18502/kss.v4i9.7347

Kusnadi, Y., \& Mutoharoh. (2016). Pengaruh Keterimaan Aplikasi Pendaftaran Online Terhadap Jumlah Pendaftar di Sekolah Dasar Negeri Jakarta. Jurnal PARADIGMA, XVIII(2), 89-101.

Lisman, A., Asnil, \& Erianjoni. (2019). Analysis of the Effect of Transformational Leadership and Work Involvement on the Performance of Environmental Officials in the West Pasaman Regency. 335(ICESSHum), 481-489. https://doi.org/10.2991/icesshum-19.2019.78

Lrviana, A. (2019). Analisis Perbandingan Persepsi Konsumen Tentang Promosi Dan Store Atmosphere Serta Pengaruhnya Terhadap Preferensi Konsumen Pada Caribou Coffee PVJ Dan Starbucks Coffee PVJ. Universitas Katolik Parahyangan, 57-77. http://repository.unpas.ac.id/32885/4/BAB III revisi.pdf

M, A. M. (2019). Disiplin Kerja dan Produktivitas Kerja. Jurnal Administrasi'ta, 3(2), 1-18.

Maiti, \& Bidinger. (1981). 済無No Title No Title. Journal of Chemical Information and Modeling, 53(9), 16891699.

Rahman, S. A., Adhitya, F., \& Erlandika, N. (2020). The Effect Of Usability Perception And Easy Perception Of Real Use In Online Purchasing Transactions. Journal of Digital Marketing and Halal Industry, 1(1), 61. https://doi.org/10.21580/jdmhi.2019.1.1.4760

Soeprajitno, E. D., Ichsannudin, \& Bahrowi, I. (2018). Ekuivalensi ( Studi Kasus pada Konsumen Stand Pakaian Pasar. Ekuivalensi, 4(2).

Susilana, R. (2015). Modul Populasi dan Sampel. Modul Praktikum, 3-4. http://file.upi.edu/Direktori/DUALMODES/PENELITIAN_PENDIDIKAN/BBM_6.pdf 